\title{
EVALUATION OF INJ. CLONIDINE IN MAINTAINING HAEMODYNAMICS DURING LAPAROSCOPIC OPERATIVE PROCEDURES
}

\author{
Todkari Kiran V1, Joshi Vyankatesh S2, Satish G. Deshpande 3 \\ ${ }_{1}^{1}$ Assistant Professor, Department of Anaesthesiology, Government Medical College, Latur. \\ ${ }^{2}$ Assistant Professor, Department of Anaesthesiology, Government Medical College, Latur. \\ 3Professor \& HOD, Department of Anaesthesiology, Government Medical College, Latur.
}

\begin{abstract}
Pneumoperitoneum usually with $\mathrm{CO}_{2}$ insufflations created during laparoscopic operative procedures affects several homeostatic systems leading to adverse effects on cardiovascular and pulmonary physiology and produces stress response. There is increase in pulse rate, systolic blood pressure and decrease in cardiac output and increase in systemic vascular resistance. Clonidine an $\alpha_{2}$ agonist with its central sympatholytic action attenuates the cardiovascular adverse effects and provide intraoperative as well as postoperative analgesia. In the present study, 60 ASA grade I and II of either sex between age range of 18-60 years and weight range of 45-70 kg were divided into 2 equal groups of 30 each. Group A served as control group A, received inj. Midazolam $0.03 \mathrm{mg} / \mathrm{kg}$ and inj. Pentazocine $0.3 \mathrm{mg} / \mathrm{kg}$ as premedication 15 minutes prior to induction of anaesthesia and group B received inj. Clonidine 1 $\mu \mathrm{gm} / \mathrm{kg}$ as premedication before induction of anaesthesia. Anaesthesia was induced with inj. Thiopentone $5 \mathrm{mg} / \mathrm{kg}$ and inj. Vecuronium $0.1 \mathrm{mg} / \mathrm{kg}$ in all patients. All patients were maintained on oxygen, nitrous oxide and inj. Propofol infusion on IPPV. Pneumoperitoneum was created with $\mathrm{CO}_{2}$ and intra-abdominal pressure was maintained on $15 \mathrm{mmHg}$. All patients were observed for changes in pulse rate, systolic blood pressure, $\mathrm{EtCO}_{2}$ throughout intraoperative period. Normocapnia was maintained. It was observed that Clonidine group provided statistically significant cardiovascular stability with less increase in pulse rate and systolic blood pressure. The requirement of additional analgesic drugs was minimum in Clonidine group with minimal sedation. Thus, it was concluded that premedication with inj. Clonidine in dose of $1 \mu \mathrm{gm} / \mathrm{kg}$ prior to induction of anaesthesia provides effective cardiovascular stability and attenuates the increase in pulse rate, systolic blood pressure, decrease in cardiac output and increase in systemic vascular resistance secondary to sympathetic stimulation secondary to pneumoperitoneum during laparoscopic surgeries.
\end{abstract}

\section{KEYWORDS}

Laparoscopy, $\mathrm{CO}_{2}$ Insufflations, Pneumoperitoneum, Sympathetic Stimulation, Stress Response, Adverse Effects, Cardiovascular System, Premedication, Attenuation, Inj. Clonidine, Analgesia, Sedation.

HOW TO CITE THIS ARTICLE: Kiran TV, Joshi Vyankatesh S, Deshpande SG. Evaluation of inj. clonidine in maintaining haemodynamics during laparoscopic operative procedures. J. Evolution Med. Dent. Sci. 2016;5(43):2661-2663, D0I $10.14260 /$ jemds/2016/623

\section{INTRODUCTION}

New techniques, use of new drugs and research in medical fraternity is key to successful outcome in any field. Adaptation of new surgical skills require corresponding developments in anaesthesia techniques. Both fields go hand-in-hand for recent advances.

Chronic cholecystitis is usually treated by open exploratory laparotomy under routine balanced anaesthesia technique. The surgical procedure ought to be prolonged one with considerable stress and strain of anaesthesia and surgery. Due to prolonged operative anaesthesia, there were chances of postoperative complications and delayed hospital stay.

Laparoscopic intervention has revolutionized tremendous ease in the procedure. To fulfil this, the anaesthesiologist has to adopt new techniques and use newer drugs in anaesthesia with minimum morbidity and mortality. Laparoscopic cholecystectomy has now become the gold standard for chronic cholecystitis. For ease of surgical procedure, creation of pneumoperitoneum is mandatory.

Financial or Other, Competing Interest: None.

Submission 16-04-2016, Peer Review 10-05-2016,

Acceptance 16-05-2016, Published 28-05-2016.

Corresponding Author:

Dr. Todkari Kiran V,

Kiran Niwas,

Vikram Nagar,

Barshi Road, Near Water Tank,

Latur-413512.

E-mail: kvtodkari81@gmail.com

DOI: $10.14260 /$ jemds/2016/623
Usually pneumoperitoneum affects several homeostatic systems leading to alteration in acid base balance, cardiovascular and respiratory physiology and stress response. Under cardiovascular there were changes as increased pulse rate, increase in mean arterial pressure, decrease in cardiac output and increase in systemic vascular resistance which in turn compromises tissue perfusion.

Various pharmacological agents are being tried to prevent haemodynamic changes associated with pneumoperitoneum. Nitroglycerin was found to correct reduction in cardiac output associated with increased pulmonary occlusion pressure and systemic vascular resistance. Beta blockers decrease the adverse effects of $\mathrm{CO}_{2}$ pneumoperitoneum. $\alpha_{2}$ agonist, Clonidine has centrally acting sympatholytic activity which in turn decreases cardiovascular adverse effects of $\mathrm{CO}_{2}$ pneumoperitoneum and provide intraoperative and postoperative analgesia. Clonidine reduces the release of catecholamines and almost blocks the release of norepinephrine. Thus, it reduces systemic vascular resistance and offers haemodynamic stability.

The present study was undertaken to implement and evaluate efficacy of Clonidine in laparoscopic cholecystectomy procedures with its effects on pressor response, haemodynamic changes and postoperative analgesia.

\section{MATERIAL AND METHODS}

Prospective placebo controlled study was undertaken in 60 patients requiring laparoscopic surgeries under general 
anaesthesia. Written informed consent was obtained from each patient. These 60 patients were divided in 2 groups as-

Group A-30 patients-received inj. Midazolam $0.03 \mathrm{mg} / \mathrm{kg}$ and inj. Pentazocine $0.3 \mathrm{mg} / \mathrm{kg} 15$ minutes before induction of anaesthesia.

Group B-30 patients-received inj, Clonidine $1 \mu \mathrm{gm} / \mathrm{kg}$ before induction of anaesthesia.

No sedation and analgesic in these patients.

ASA Grade I and II between age range of 18-60 years of either sex and between $45-70 \mathrm{~kg}$ weight range posted for laparoscopic abdominal surgery were selected. The patients with hypertension, ischemic heart disease, obstructive airway disease, severe renal and hepatic disease and diabetes mellitus were excluded from the study. The patients on beta blockers, benzodiazepines, MAO inhibitors were also excluded. All patients were pre-anaesthetically evaluated for fitness of anaesthesia. On the operation table after checking monitoring devices, IV infusion was set up. All patients were induced with inj. Thiopentone sodium $5 \mathrm{mg} / \mathrm{kg}$ and Inj. Vecuronium 0.1 $\mathrm{mg} / \mathrm{g}$ with priming principle. After endotracheal intubation, all patients were maintained on Oxygen, nitrous oxide on IPPV with inj. Propofol infusion. Pneumoperitoneum was created by insufflations of $\mathrm{CO}_{2}$ in $15^{\circ}$ reverse Trendelenburg position. Intra-abdominal pressure was not allowed to exceed $15 \mathrm{mmHg}$ throughout surgical procedure. All patients were maintained normocapnia by end tidal $\mathrm{CO}_{2}$ on capnography. Mean $\mathrm{EtCO}_{2}$ in control group was $31.94 \pm 0.78$ and in Clonidine group was $31.91 \pm 0.55 \mathrm{mmHg}$. There was no significant difference in two groups. (Mention how you measured $\mathrm{CO}_{2}$ ). At the end of operative procedure, reversal was carried out with inj. Glycopyrrolate $1 \mu \mathrm{gm} / \mathrm{kg}$ and inj. Neostigmine $.04 \mathrm{mg} / \mathrm{kg}$ diluted in saline. Intraoperatively pulse rate, blood pressure, $\mathrm{SpO}_{2}$ and ECG were noted as pre-induction, post-induction and post-intubation.

Pulse rate, systolic blood pressure and $\mathrm{SpO}_{2}$ were monitored prior to induction, after intubation for every 5 minutes up to 15 minutes, every 15 minutes till end of surgery and 15 minutes postoperatively. $\mathrm{EtCO}_{2}$ was noted. Postoperative sedation was noted as sedation score as 1awake and agitated, 2-awake and comfortable, 3-asleep but arousable and 4-asleep with sluggish response. Postoperative analgesic requirement was also noted by using Visual analogue scale. All observations were statistically analysed by Chi-square test or Fisher analysis and unpaired t test.

\section{OBSERVATIONS}

60 patients were divided into 2 groups. The demographic data was as shown in Table No. I.

There were 27 male and 33 female patients in 2 groups. There was no significant difference in mean age range in control and Clonidine group. Preoperative investigations were within normal limits in all patients.

Mean pulse rate and systolic blood pressure were noted preoperatively, intraoperative and postoperatively as shown in Table No. II.

Preoperatively, mean pulse rate and blood pressure were comparable in both groups. Intraoperatively, mean pulse rate and systolic blood pressure were significantly on lower side in Clonidine group as compared to control group. The difference was statistically significant. Postoperatively, also there was statistically significant difference in mean pulse rate and systolic blood pressure in Clonidine group as compared to control group.

Intraoperative $\mathrm{EtCO}_{2}$ was $31.94 \pm 0.78 \mathrm{mmHg}$ in control group and $31.91 \pm 0.55 \mathrm{mmHg}$ in Clonidine group thus showing normocapnia.

The time required for rescue analgesia was as shown in Table No. III.

Significantly, longer time for rescue analgesia was noted in Clonidine group as compared to control group.

Postoperative sedation was $36 \pm 15$ minutes in control group and $35.33 \pm 5.07$ minutes in Clonidine, which was comparable in both groups.

RESULTS

\begin{tabular}{|c|c|c|}
\hline Parameter & $\begin{array}{l}\text { Group A } \\
\text { Control }\end{array}$ & $\begin{array}{c}\text { Group B } \\
\text { Inj. Clonidine }\end{array}$ \\
\hline Mean age in years & $48.38 \pm 11.58$ & $45.77 \pm 16.59$ \\
\hline Male/Female ratio & $15 / 15$ & $12 / 18$ \\
\hline Mean weight in kg & $57.16 \pm 5.53$ & $55.0 \pm 11.24$ \\
\hline Total Patients & 30 & 30 \\
\hline
\end{tabular}

\begin{tabular}{|c|c|c|}
\hline Parameter & $\begin{array}{c}\text { Mean Pulse } \\
\text { Rate }\end{array}$ & $\begin{array}{c}\text { Mean Systolic } \\
\text { BP }\end{array}$ \\
\hline Group A-Control & \\
\hline Preoperative & $78.03 \pm 6.76$ & $132.71 \pm 4.28$ \\
\hline Intraoperative & $90.82 \pm 4.81$ & $137.87 \pm 4.89$ \\
\hline Postoperative & $92.67 \pm 5.74$ & $139.08 \pm 2.63$ \\
\hline Group B-Clonidine & $80.76 \pm 7.89$ & $128.76 \pm 8.59$ \\
\hline Preoperative & $74.76 \pm 9.86$ & $125.79 \pm 6.44$ \\
\hline Intraoperative & $78.03 \pm 6.97$ & $128.88 \pm 5.82$ \\
\hline Postoperative & Table II: Showing Vital Parameters \\
\hline \multicolumn{3}{|c|}{} \\
\hline
\end{tabular}

\begin{tabular}{|c|c|c|}
\hline $\begin{array}{l}\text { Time in } \\
\text { Minutes }\end{array}$ & Group A & Group B \\
\cline { 2 - 3 } & $116.05 \pm 19.17$ & $334.83 \pm 24.65$ \\
\hline \multicolumn{2}{|c|}{ Table III: Time for Rescue Analgesia } \\
\hline
\end{tabular}

\section{DISCUSSION}

In recent past, laparoscopy has established its own position in surgical procedures. For performing these laparoscopic procedures, many times anaesthesiologist has to face new challenges and adopt new techniques of anaesthesia. Various gases as air, nitrous oxide, $\mathrm{CO}_{2}$ have been used to create pneumoperitoneum for laparoscopic surgeries. Recently, air or $\mathrm{CO}_{2}$ are usually used according to the availability of $\mathrm{CO}_{2}$ gas.

Pneumoperitoneum during laparoscopy produces significant haemodynamic changes such as increase in mean arterial pressure, increase in pulse rate, decrease in cardiac output and increase in systemic vascular resistance which in turn compromises tissue perfusion dreadful in elderly and haemodynamically unstable patients (Dhoste $\mathrm{k}$ et al 1996). ${ }^{1}$ Clonidine is imidazoline derivative, a selective $\alpha_{2}$ adrenergic agonist. It produces decrease in elevated pulse rate and systolic blood pressure with decrease in systemic vascular resistance and cardiac output.

In the present study, we have used inj. Clonidine 1 $\mu \mathrm{gm} / \mathrm{kg}$ IV 15 minutes prior to induction of anaesthesia. Goyagi T et al (1996), ${ }^{2}$ Aho et al (1992), ${ }^{3}$ Joris et al (1995),, Melek et al (1999), ${ }^{5}$ Sung et al (2000), ${ }^{6}$ and YU et al (2003) ${ }^{7}$ have used inj. Clonidine in various doses before induction of 
anaesthesia in their patients posted for laparoscopic surgical procedures. Melek et al (1999). ${ }^{5}$ used $150 \mu \mathrm{gm}$ of inj. Clonidine infusion, while Sung et al (2000). ${ }^{6}$ and YU et al (2003). ${ }^{7}$ used $150 \mu \mathrm{gm}$ of oral Clonidine as premedication for maintenance of haemodynamic stability due to pneumoperitoneum. They noted that Clonidine prevented adverse effects of pneumoperitoneum and provided significant cardiovascular stability as changes in pulse rate and systolic blood pressure.

In the present study, we used inj. Clonidine in dose 1 $\mu \mathrm{gm} / \mathrm{kg}$ as like above authors as premedication before induction of anaesthesia. During intraoperative and immediate postoperatively there was significant decrease in pulse rate and systolic blood pressure in Clonidine group as compared to control group at all-time intervals. Thus premedication with Clonidine decreased incidence and ill effects of laparoscopic haemodynamic after creation of pneumoperitoneum. Normocapnia was maintained in both groups intraoperatively. Postoperative sedation was comparable in both groups. Clonidine also provided postoperative analgesia as compared to control group for considerable time interval. Our observations coincide with Hsiech CH (2003), ${ }^{8}$ Koivusalo AM et al (1998), ${ }^{9}$ Hirvonen EA et al (2000), ${ }^{10}$ Joris et al (1995),, Goyagi T et al (1996), ${ }^{3}$ Melek et al (1999), ${ }^{5}$ Sung et al $(2000)^{6}$ and Yu et al (2003). ${ }^{7}$

Thus, Clonidine was found to be relatively safe, effective for providing stable haemodynamic status in laparoscopic operative procedures under general anaesthesia. It protects the patient from stress response triggered by pneumoperitoneum undergoing laparoscopic cholecystectomy. It also provides intraoperative and postoperative analgesia with minimal sedation.

\section{CONCLUSIONS}

Clonidine is $\alpha_{2}$ agonist, is centrally acting sympatholytic agent which reduces adverse effects of $\mathrm{CO}_{2}$ pneumoperitoneum and provide intraoperative and postoperative analgesia. From the present study, it can be concluded that premedication with inj. Clonidine in dose of $1 \mu \mathrm{gm} / \mathrm{kg}$ prior to induction of anaesthesia can provide haemodynamic stability in the form of stable heart rate, systolic blood pressure, minimal postoperative sedation and good postoperative analgesia.

\section{REFERENCES}

1. Dhoste K, Lacoste L, Karayan J, et al. Haemodynamic and ventilatory changes during laparoscopic cholecystectomy in elderly ASA grade III patients. Can Jr Anaesth 1996;43(8):783-788.

2. Goyagi $\mathrm{T}$, Nishikawa $\mathrm{T}$. Oral clonidine premedication causes the quality of postoperative analgesics by intrathecal morphine. Anaesth Analg 1996;82(6):11921196

3. Aho M, Scheinin M, Lehtinen AM, et al. Intramuscularly administered dexmedetomidine attenuates haemodynamic and stress responses to gynaecologic laparoscopy. Anaesth Analg 1992;75(6):932-939.

4. Joris J, Chiche JD, Lamy M. Clonidine reduced haemodynamic changes induced by pneumoperitoneum during laparoscopic cholecystectomy. British Jr Anaesth 1995;74(suppl):A124.

5. Melek KJ, Knor J, Kurzova A, et al. Adverse haemodynamic changes during laparoscopic chole-cystectomy and their possible suppression with clonidine premedication. comparison with intravenous and intramuscular premedication. Rozhi Chir 1999;78:286-291.

6. Sung CS, Lin $\mathrm{SH}$, Chan $\mathrm{KH}$, et al. Effect of oral clonidine premedication on postoperative response and postoperative analgesic requirement for patients undergoing laparoscopic cholecystectomy. Acta Anasthes Scand 2000;38:23-29.

7. YU HP, Hseu SS, Yein HW, et al. Oral clonidine premedication preserves heart rate variability for patients undergoing laparoscopic cholecystectomy. Acta Anaesth Scand 2003;47(2):185-190.

8. Hsiec CH. Laparoscopic cholecystectomy for patients with chronic obstructive pulmonary disease. J Laparoscopic Adv Surg Tech A 2003;13(1):5-9.

9. Koivusalo AM, Scheinin M, Tikkanen I, et al. Effects of esmolol on haemodynamic response to $\mathrm{CO}_{2}$ pneumoperitoneum for laparoscopic surgery. Acta Anaesthesiol Scand 1998;42(5):510-517.

10. Hirvonen EA, Poikolainen EO, Paakkonen ME, et al. The adverse haemodynamic effects of anaesthesia, head-up tilt and carbon dioxide pneumoperitoneum during laparoscopic chole-cystectomy. Surg Endosc 2000;14(3):272-277. 